\title{
Language and Violence in Edward Albee's The American Dream
}

\author{
Ayşe Gülsüm KARAALIOĞ $\breve{L} U^{1}$ \\ Ferma LEKESIZALIN ${ }^{2}$
}

\begin{abstract}
Family dysfunction has been a recurrent dramatic theme which has attracted a great deal of attention in both the modern and the postmodern era. In an unfortunate sort of way, most of the families in the 20th century plays are unable to function the way they are supposed to. The family members to whom the audience is introduced cannot attain peace and harmony; they are entangled in a seemingly endless struggle for power and control; and, at times, it gets closer to a Machiavellian world where one pitilessly deceives the other, following a series of dishonest strategies and tactics. Alps on alps arise when one can find no single character who might be referred to as an 'ideal person', as 'an example of who and what individuals should all aspire to be'. Being in the presence of others, being with the other human beings, which is the actual basis of social life, is what becomes problematic as an existentiale. Hell is nothing, but being with the other or the others, in Jean Paul Sartre's terms. The apparently stuck characters, who struggle to acquire an identity by avoiding victimization and nothingness, are not able to move forward in the existential hell of self-conscious paralysis. Moreover, due to the disappearance of individualism in a mechanized and standardized society, individuals tend to show extreme kind of behaviours. The old and honest American Dream is replaced by a new society concerned with consumerism; and, as a matter of fact, 'language and violence' comes to the forefront as an important point worthy of attention. The issue of verbal violence, which revolves around statements with negative connotations, brings with itself domestic problems waiting to be solved. The actions, reactions and interactions, which stand in stark
\end{abstract}

\footnotetext{
${ }^{1}$ PhD Candidate, Istanbul Aydin University, Istanbul, aysekaraalioglu@stu.aydin.edu.tr, https://orcid.org/0000-0002-2164-0758

${ }^{2}$ Prof. Dr., Istanbul Ayvansaray University, Istanbul, fermalekesizalin@ayvansaray.edu.tr, https://orcid.org/0000-0001-5222-4135

Research Article - Submit Date: 07.02.2021, Acceptance Date: 09.03.2021

DOI: 10.17932/IAU.IJMCL.2015.014/ijmcl_v07i1006
} 
contrast to the socially acceptable norms and values, are important, as they constitute the material to dig and delve deep into the deeds done for dominance, and as they are rich enough materials to bring out the diversions from the ideal family picture. This study focuses on one of Edward Albee's most famous works, The American Dream, examines the family, the paradoxical union, as portrayed in a modern wasteland, and explains the forms and consequences of violence, most specifically the verbal violence.

Keywords: Family, Language, Violence, Existentialism

\section{ÖZ}

Aile disfonksiyonelliği, hem modern hem de modern-sonrası çağda üzerinde yaygın olarak durulan bir tema olmuştur. 20. yüzyıl oyunlarında öne çıkan ailelerin çoğu, talihsiz bir şekilde, olması gerektiği gibi işleyememektedir. İzleyici karşısındaki aile fertleri, barış ve uyum sağlayabilme konusunda yetkin değillerdir; güç ve kontrolü ele geçirebilmek için, sonu gelmeyen bir savaşa tutulmuşlardır; ve, yaşamakta oldukları dünya, zaman zaman, birinin bir diğerini, birtakım aldatıcı stratejiler ve taktikler kullanarak acımasızca kandırdığ 1 Makyavelci bir dünyaya doğru yaklaşır. Oyunlarda, 'ideal bir kişi', 'kim ve nasıl bir insan olunması gerektiğini gösteren bir örnek' bulunmadığı hallerde, durum daha da ciddi bir şekil alır. Bir var oluş hali olarak sorun teşkil eden şey, sosyal yaşamın temelini oluşturan, başka bireylerin huzurunda olma, başka insanlarla bir arada olma durumunun kendisinden başka bir şey değildir. Jean Paul Sartre'a göre, cehennem, diğer kişi ya da kişilerle bir arada olma halidir. Esaretten ve hiçlik duygusundan sakınarak, bir kimlik edinme çabasında olan, kilitlenip kaldıkları aşikâr olan karakterler, bilinçlerinin adeta felç olduğu varoluşsal cehennemde yol alamamaktadırlar. Ayrıca, makineleştirilmiş ve standardize edilmiş bir toplumda bireyselliğin yerle bir edilmesiyle bağlantılı olarak, insanlar uç noktalarda olan davranışlar sergileme eğilimindedirler. Eski, dürüst Amerikan Rüyası'nın yerini, tüketicilikle meşgul yeni bir toplum almıştır; ve, doğal olarak, 'dil ve şiddet' üzerinde durulması gereken bir konu olarak ön plana çıkmaktadır. Negatif çağrışım yüklü ifadeler etrafında dönüp dolaşan, sözsel şiddet konusu, beraberinde çözülmesi gereken ailevi problemler getirmektedir. Baskın karakter olmak için başvurulan davranış modellerini irdeleyebilme, ve ideal aile tablosundan sapmaları ortaya koyabilmeleri açısından yararlı malzemeler sağladıkları için, toplum tarafından kabul gören norm ve değerlere tezat teşkil eden eylemler, tepkiler ve etkileşimler araştırılması gereken bir konudur. $\mathrm{Bu}$ çalışma, Edward Albee'nin en ünlü eserlerinden olan The American Dream adlı oyuna odaklanarak, paradoksal bir birlik haline dönüşen aile kurumunu, modern ancak çoraklaşmış ortamında incelemektedir ve büyük ölçüde, söze dayalı olan şiddetin şekillerini ve sonuçlarını ele almaktadır.

Anahtar Kelimeler: Aile, Dil, Şiddet, Varoluşçuluk 


\section{INTRODUCTION}

Modern American drama has frequently dealt with families that stand in stark contrast to traditional ones. Since reciprocal responsibilities are sometimes disregarded, individuals living under the same roof come face to face with nothing, but problems. Successions of empty clichés, which under normal circumstances are considered as disturbing utterances, are heard; and, ideal qualities - such as democracy, honesty, morality, standards, conventional values, acceptable behaviours, positive feelings, liberality of spirit, and peace and generosity of mind - no longer reign. What is significant about some of the 20th century plays is that no healthy connection can be maintained among family members. What subsequently turns everything upside down is the impaired functioning within the unit; and, families which exist outside the clear-cut 'normal' boundaries, which do not act by following a shared commitment to the mutual relationship, cannot escape the risk of being doomed to failure. There is a common fallacy about the ideal American family; and, the family members are only united due to the compelling force of habit; and, the familial unit is, simultaneously and paradoxically, the source of both pain and consolation.

In the plays which are labeled 'modern', the standard or naturalistic conventions of plot, characterization, and thematic structure are distorted for the sole purpose of conveying the irrational or fictitious nature of reality, and the essential and inevitable isolation of humanity in a senseless world. The major aim behind all these is to examine the absurdity of the human condition and expose the experiences of alienation, insanity, and despair inherent in modernity. To achieve the desired dramatic effect, the futility of human struggle is portrayed by bizarre or fantastic means, deliberately confusing actions, and disjointed and repetitive kind of dialogues. Encompassing the work of playwrights as divergent as Samuel Beckett, Eugène Ionesco, Jean Genet, and Harold Pinter, the dramatic movement of 'absurdism' is greatly influenced by Existentialism; and, belonging to the category of the 'theatre of the absurd', Edward Albee incorporates ridiculous, incongruous, and inappropriate elements - details contrary to all reason or common sense - into his plays which, at certain stages, prove Jean Paul Sartre's conviction that "Hell is - other people!" (Sartre, n.d., p. 47).

As in Eugene O'Neill's and Sam Shepard's family plays, an aspect that attracts attention in Albee's The American Dream is the victimization of the other, and thus, man's struggle to avoid victimization by the other. Man desperately tries to find something to hold on to, something to cling to, something that can count as a raison d'être in an age of loneliness, alienation, dehumanization, and estrangement. To be able to escape the victimization of the other - the other man, or the society in general - one has no alternative apart from victimizing the other, and thus, hell becomes nothing, but the other or the others, in Sartre's terminology. With the intention of avoiding non-being, the characters rebel to be 
victimized by external forces, by threats coming from outside. They, heart and soul, struggle to establish an identity to avoid nothingness. The family's mutually destructive dependency on one another is the symbiotic nightmare of the family. Between the members of the family, there is an essential relationship of dependence; each provides for the other the conditions which are necessary for a continued existence.

Although the name of the monster is never explicitly stated, or verbalized in the plays, its characteristics indicate that it is capitalism, which is the economic, political and social system based on private ownership of property, business and industry to make the greatest possible profits. The ruthless economic system, the quest for higher profit margins, the excessively greedy mindsets, the extreme wish for material gain, the revealing of the materialistic side, the lust for money, and the idolization of wealth all combine to create a numb society, which is devoid of feeling; and, the callous individuals in the dominant roles struggle to have the utmost power and privilege. What is more, the ideological differences between generations have the tendency to take the matter to different dimensions; and, the extent of the American Dream - a dream which inherently prioritizes liberty, justice, fairness, and equality over money - may differ for each member of a family, and eventually lead to disagreements, and verbal fights in domestic environments. Instead of struggling to encapsulate and pursue the American Dream, individuals with exaggerated entrepreneurial spirits tend to head towards some other directions. The result is the complete distortion, the perverted version of the American Dream. With the circumstances being so, the ones who are under pressure choose to speak in the language of violence.

\section{THE MATRIARCHAL COMPLEX AND THE STRATEGIES FOR DOMINANCE}

Drama is nothing, but "a mimesis of real life"; "[t]he theatre is a simulacrum" of the actual world and actual life; and, this is the reason why Antonin Artaud, the Surrealist 'prophet', "called his book The Theatre and Its Double" (Esslin, 1988, p. 176). According to Artaud, who is one of the main inspirations of the theatre of the absurd, and who is known for his 'theatre of cruelty', it is a fatal mistake to separate theatre from life. Likewise, in his play The American Dream - which was first produced at the York Playhouse, New York City, on January 24, 1961 (Albee, 2007, p. 97) - Albee presents the audience with a broad canvas of real life, the sacrosanct fraud of an American family, a picture of modern times which shows the anguish of all; and, as a matter of fact, 'language and violence' emerges as a defining theme which deserves considerable attention. In Albee's work, it is possible to sense the ideas of Artaud, who - in an open letter to the schools of Buddha - rejects logic and reason as "the chains that bind us in a petrifying 
imbecility of the mind" (as cited in Innes, 2005, p. 59). In the play under scrutiny, misdeeds spring from mistaken mentalities; and, one exerts strong authoritarian control over the others, and keeps on carrying out verbal violence, in a quite determined way.

The moment The American Dream - which is a play in one, uninterrupted scene - opens, the audience is invited into the house of three cartoonishly exaggerated characters: A terribly efficient, selfish, catty, dominant, and sadistic Mommy; a vague, inept, enfeebled, and emasculated Daddy; and, a witty, wise-cracking, and embittered Grandma, who is the only sensible character who gives a semblance of meaning to the rest, and who later reveals herself as an enlightened critic. Their comical use and abuse of language is not a consequence of linguistic incompetence at all; it is a planned and "concerted effort" to free their selves from the "human obligations" which are "implied by communication" (Berkowitz, 1992 , p. 128). What is unusual about the names of the characters is that the married duo has no proper names; the nameless characters are defined by their place within the family structure, which also adds gravity to the chaotic atmosphere of the play, perhaps hinting at or highlighting the lack of genuine intimacy between the members of the family. The situation of having no specific names provides the audience with a certain clue, with a certain impression, from the very beginning that the story is to be unfolded and told from their child's perspective.

Throughout the play, what catches most of the attention is Grandma's defenses against the violence of social intercourse. Mommy makes Grandma's life nearly impossible in the "stuffy apartment of Ionesco motifs", somewhere within which Albee "places a family in the American grain, with its areas for senior citizens, and its focus on money" (Cohn, 1969, p. 12). It is a play where talks of "twentyfive thousand smackerolas" can be heard; it is a play where, instead of words of affection, a statement like "Money talks" can echo (Albee, 2007, p. 137). During the encounter with Mommy's sadism, one can do nothing apart from accepting her as she is, because it seems to be the only way out. Even when there is some kind of logic in her mania, which is seldom, it is not easy to ignore her monsterlike attitudes, and the sadistic pleasure she gets from being the one who is in control of the situation. In order to check how carefully Daddy listens to the nonsense she talks, she repeats the same pair of questions: "What did I say? What did I just say?" (pp. 100-101). She does all these just to cause trouble for Daddy.

With language being "employed as dialectic" and as a way of "exorcism", new positions are reached by testing some opposing views against each other. The metaphysics of cliché is used to show "the sterile and outworn lives" of the couple (Oberg, 1966, p. 142). The apartment is "an emotional void", a blank space which "sterilizes and petrifies the manners and ceremonies of human life"; and, the couple's "vague [and] cliché-filled" dialogue is "a measure of the vacuum" in 
which they are condemned to live, "of the absence of essential contact" between two people "reduced to suffering" each other's presence (Debusscher, 1967, pp. 37-38). In this context, Sartre's ideas about the look and the perpetual ontological fight of being caused to see oneself as an object from the eyes, from the view, of another consciousness, and his Huis Clos (No Exit) - the predecessor of the theatre of the absurd, and the source of his famous quotation about the source of 'hell'- constitute another point of departure for the explanation of the relationships in the play. Being squeezed into a claustrophobic room with some others, Sartre's hero, Garcin, takes it from an existential standpoint, and concludes with the key statement of the play:

I'm looking at this thing . . . and I understand that I'm in hell . . [E]verything's been thought out beforehand ... [A]ll those eyes intent on me. Devouring me ... Only two of you? I thought there were more; many more. So this is hell. ... You remember all we were told about the torture-chambers, the fire and brimstone, the 'burning marl.' Old wives' tales! There's no need for red-hot pokers. Hell is - other people! (Sartre, n.d., pp. 46-47)

In parallelism with these explanations, in Albee's play, Mommy creates a helllike living environment for both her mother and her husband. Because of its strident - loud and forceful - tone, exaggerated sarcasm, shrillness, and even derision, Mommy's way of talking distinguishes itself as the most aggressive one in the house. Her speech, which is utterly unpleasant and painful to listen to, has an incredible capacity for violence. As in Sartre's play, their hell is not a fiery furnace with flames, but a hell of psyche, a hell of their imprisoning mind.

The polarity embodied in Mommy and her mother reaches unprecedented heights. With her plots, intrigues, and sheer egotism, the disciplinarian and tyrannical Mommy frequently threatens Grandma with a man in a van - an imaginary, 'made-up' figure - who will cart her away, to a nursing home: "Well, why don't you call a van and have her taken away?" (Albee, 2007, p. 120) "Away you'll go; in a van" (p. 130). Underneath her skin is her murderous malice. Her speech is shaped by hyperbole; she speaks in such a misleading way that she makes herself sound bigger than everyone else, better than everyone else, and much more important than her real self. She wants to make life convenient for herself, even if this means getting rid of Grandma, who has become nothing, but a nuisance in her eyes. Mommy rebukes Grandma for reading her "book club selections" (p. 104), stubbornly devalues her words, and generally attacks her with her imperative kind of sentences. Mommy, who cannot stand Grandma's constant "housework" (p. 105), exists just to exert her will on others, and gets 
satisfaction by insisting on her own ways. Mommy, whose unswerving intentions are disturbing to the senses, has a natural talent for asserting her will. She discusses Grandma's toilet habits, worries about her vocabulary, and comments on the borrowed language she uses and says, "I don't know where she gets the words; on the television, maybe" (p. 121). Her violence is crystal clear when she says, "Daddy, go break her television" (p. 123); and, from this quotation, one can infer that the mother-daughter relationship is rotten to the core. The audience is confronted with repetition as a kind of hell.

In Albee's words, The American Dream is "an examination of the American Scene, an attack on the substitution of artificial for real values in our society, a condemnation of complacency, cruelty, emasculation, and vacuity; it is a stand against the fiction that everything in this slipping land of ours is peachy-keen" (as cited in Shiach, 2007, p. 43). In this critique of the American way of life, Mommy - the archetypal, consummate 'bad mother' - not only dismisses her mother, but also infantilizes and emasculates Daddy, who is a man stranded in a house of women. Mommy and Daddy seated on either side of the living room, talking aimlessly, obviously reminds the audience of the setting and the dialogue of Mr. and Mrs. Smith at the beginning of Eugène Ionesco's The Bald Soprano. Some details which call to mind the Ionescoean techniques - the use of props, the proliferation of objects such as Grandma's innumerable boxes, the act of toying with the language, the pointless anecdotes and refrains, and the meaningless nuances such as "beige", "wheat" or "cream" - unite to create an atmosphere of violence. With her self-indulgence in triviality, the phobic Mommy forces Daddy to echo her banal and seemingly pointless story about the "beige hat", reduces him to her diligent listener, chastises him for his inattentive listening, tells him to "[p]ay attention" while listening, prompts and repeats his speech in a patronizing manner, turns him into an acoustic mirror, terrorizes him into obedience, tries to reduce him to unmanly impotence, bullies him, dismisses and makes fun of him with a laugh, and always uses forceful speech to rule him (Albee, 2007, pp. 99101). What she wants is getting satisfaction in being heard. She quite well knows that the hat she took back to the shop and the hat she was given in exchange for it are the same, but this is no problem for her, as all that matters is the act of acting, the act itself. She avoids taking chances, and carefully watches for signs of regression. There is much beneath the surface of the perverse reversal of the side of authority, and the matriarchal complex, which reduces the head of the family to someone so ineffective and so insignificant. Mommy's ruthless attacks on Daddy absolutely show a disregard for his personality.

The liberation movements in the mid-century legitimized various kinds of personal expression. "Women's position in society was [altogether] transformed ... because of changes in employment ... and the demands of feminism" (Unwin, in Unwin \& Woddis, 2001, p. ix). The institution of the family, which was the 
narrowly defined basic unit of society, transformed into something multi-formed and diverse. In the house where they have to live under the same roof, Grandma even calls Mommy "a tramp and a trollop". It is such a chaotic place that she even expresses her disapproval about Daddy's marriage to her demonic daughter (Albee, 2007, p. 107). Mommy, who has a pathological obsession with authority, continuously assaults Daddy, mocks his aspirations, and ridicules his manliness with her encouragement. For instance, when the doorbell rings, the sentence uttered by Mommy - "Open the door" (p. 110) - is one sign of Mommy's domination in the house. Having withdrawn into a self-absorption from which they stir themselves only with intense difficulty, it takes the masochistic Daddy - who waffles on whether or not to open the door, and who in so many ways acts as Mommy's subordinate - several pages to gather up the energy, determination, and doggedness to head towards the door, and answer the ringing doorbell. His pathetic attempt to prove his oppressed masculinity is quite obvious when he goes to open the door, and when he says, "Was I firm about it?", "[W]as I decisive?" "And masculine? Was I really masculine?" Mommy's praising of Daddy's 'firm' masculinity - "[Y]ou were masculine. . . . [S]o masculine" (pp. 110-111) - is nothing other than a nauseating flattery. There is a hypnotic quality about the dialogue; and, the hysterical wife's extended form, or possibly storm, of encouragement to open the door and demonstrate his strength and masculinity is an attempt which emasculates the father further and further. While opening the door, his masochism is made even more explicit; he submits to the particular demonstration of manliness that his wife stubbornly demands. This ritual of demonstration and the humiliation which follows are typical of masochistic fantasy.

The reason behind Mommy's selfishness is her perverted sexual instincts. She castrates Daddy's masculine superiority as delicately as "the doctors took out something that was there and put in something that wasn't there" (Albee, 2007, p. 117). Just because Grandma calls Daddy "a hedgehog" (p. 120), Mommy who thinks that she picked up the word from nowhere, but television - orders Daddy to shake her television's tubes loose. This latter point also includes elements of violence within itself; the reason becomes clear when Daddy reacts by telling her not to "mention tubes to [him]". Daddy "has tubes now", where he once had tracts (p. 121). Related to this poignant reminder, related to the destructive capacity of language, there is a further point on which emphasis needs to be placed: In order to torture their guest, Mrs. Barker, a number of conversational games are staged; and, resembling the ways of a maniac, Mommy not only insists that Mrs. Barker not smoke, but also sarcastically muses on her good fortune in marriage. Mommy could have married a man "who was poor", "argumentative", or consigned to "a wheelchair". Obviously, recalling Mrs. Barker's invalid husband, and thus, causing a sharp feeling of sadness, Mommy feels horror deep inside; and, Mrs. Barker, "forcing a smile", tells her to forget 
about it. The sudden crude revelations of unspoken impulses make the place even more hell-like. While commenting on the random words she used about not having a husband sitting in a wheelchair, Mommy switches to another language which involves blood and savagery: The audience is exposed to totally violent imagery when she says, "I could cut my tongue out!" (p. 123). As a reaction to this, Mrs. Barker, an ingenuous outsider who apparently cannot stand games, becomes frail and almost faints, as a result (p. 124). Feeling obliged, the immature Daddy, who never has anything important to say, tries in his own way to be a kind and adorable husband. He has almost succeeded in doing that; however, "psychologically, he is already in a "wheel chair"" (Paolucci, 1972, p. 30). There is always the understanding that, in the domestic sense, a surgically emasculated Daddy cannot be the head of the family. What Daddy wants to hear is that he is masculine; it is what he specifically wants to hear, as it is what he is not.

A phenomenon like the 'theatre of the absurd' does not intend to show despair, but it aims at demonstrating modern man's efforts to come to terms with the world in which he is condemned to live. It tries to make him come face to face with the human condition as it really is. Despite the neatly wrapped lunch boxes Grandma prepared for Mommy in the past, and all the deprivation she suffered - she denied herself dinner to provide her daughter with the following day's lunch - Mommy behaves like a monster, resisting to each and every word Grandma utters. Being innately sly and hypocritical, Mommy has always known how to make her way through the difficulties and obstacles of life. She was even successful in getting her classmates to give her their own snacks, which can be referred to as another version or extension of violence. She used to say, "Oh, look at my lovely lunch box; it's so nicely wrapped it would break my heart to open it." And, because she did not open the beautifully wrapped 'gift', she, playing the deprived child to her classmates, fed herself on the other children's food (Albee, 2007, p. 105).

\section{THE CONSEQUENCES OF THE VERBAL VIOLENCE}

While dispossession gives human beings something, a valid enough reason, to fight against, the instinctive need for security and recognition gives them something to fight for; and, the desire to fight, in a way, becomes synonymous with the desire to live. Confronting anxiety is what gives the individual the strength, the power, to confront the human condition, naturally breeding the vitality which is essential to come to terms with the world in which he is struggling to live. In Sartre's No Exit - where the mistreatment of a wife, the seduction by a manipulative and misandrist sadist, the act of asphyxiating oneself, the 'on purpose' flooding of a room with gas, the killing of a child who was born as a result of an unfortunate affair, and the suicide committed are all forms and symptoms of violence - man is condemned to stay within the surrounding walls 
till the end of his life. Even though the degree, the extent, of the violence varies, The American Dream, likewise, is full of moments of aggression; and, Daddy and Grandma have to endure the heartlessness and the blatant mistreatments of Mommy, who always causes needless problems, and creates a series of seemingly unbearable conditions in the house. The effect Mommy's enthralling sadism generates is one of passivity, a masochistic submission to the violence she stages. The qualities of ineffectualness and resignation in the father's character are so interwoven, and so interconnected that "Oh dear; oh dear" becomes his typical response, his only reaction to whatever happens (Albee, 2007, p. 110).

Existential man ought to find some social or political cause to be able to acquire some dignity and purpose, to bolster his identity. In this context, a great deal is revealed in Albee's play; and, it has something in common with Sartre's No Exit, which is "about the manoeuvring of ... people" who are "forced to share a small room together in hell" (Styan, 1996, p. 118). As in Sartre's existential hell of selfconscious paralysis in No Exit, the characters in Albee's play, who are exposed to the presence of each other in a closed and shared area, seem unable to move forward. Each and every behaviour takes the form of a problem, turns into attitudes which result in unwanted consequences, and eventually transforms the house into a soul-sucking living environment, that is, into hell. In his play, the title of which is already an indication that the work deals with some kind of hermetically sealed space, Sartre puts forward his view that "life in society is hell", and points out that "hell is a "drawing room in Second Empire style."' (Szondi, 1987, p. 61). Resonances of these aspects can be seen and sensed in The American Dream. The utterly transcendental situation of hell hints at the picture where one becomes the other's torturer. The moment identity breaks down and one face becomes indistinguishable from another face, the other altogether dissolves, like a solid being absorbed by a liquid. It disappears, goes out of sight, as it is consumed by the force which comes from outside. Hell is then, by necessity, oneself.

The fundamental focus in The American Dream is the inevitable "collapse of communality, the [o]ther as threat"; and, the subject matter is "loss, desolation, [and] spiritual depletion" (Bigsby, 2000, p. 125). With the tempestuous argument scenes in front of her eyes, and in her tortured mind, Grandma - whose character is "based ... on [Albee's] own (adoptive) maternal grandmother" (Albee, 2006, p. 168) - tries to protect, armor, herself against the violence her daughter stages. The mother-daughter relationship is a long scene of cruel bullying insult. According to Grandma, elder people, who are marginalized within the 'American Scene', are the targets and victims of violent social intercourse. Her epigrammatic wit, memory lapses, on-purpose deafness, crudity, and senility help her a lot when dealing with that kind of verbal violence. Grandma is the one who continuously comes up with sardonic epigrams on the position of the elderly individuals: 
When you get old, you can't talk to people because [they] snap at you. . . . That's why you become deaf, so you won't be able to hear people talking to you that way. And that's why you go and hide under the covers in the big soft bed, so you won't feel the house shaking from people talking to you that way. (Albee, 2007, p. 104)

It is the annoying speech of the others which results in their passing away, and, perhaps, the best defense mechanism the elderly ones have, and thus Grandma has, is pretending to be deaf. It is her deafness which removes, which detaches her from the fatal intercourse. The implication behind the repetitive use of the clichés of middle-class America is that such kind of utterances will have a direct effect on the death of Grandma, who represents the strong, "vigorous old frontier spirit". It is her daughter who "delivers the punches", but she cannot literally kill Grandma, who, due to her age, has become crafty, and has learnt how to "roll with the punches" which come quite frequently (Cohn, 1969, p. 11).

Being a down-to-earth sort of woman, Grandma quite remarkably underlines the severity of the violence, which is staged against the elderly, in social intercourse: "I suppose I deserve being talked to that way. . . . Most people think that when you get so old, you either freeze to death, or you burn up" (Albee, 2007, p. 104). Being in the grips of the childlike quality of senility, she pathetically says that "[o]ld people have nothing to say", and that, "if [they] did have something to say", unfortunately, no one would listen to them (p. 119). It is the usage of the emphasis 'do' and the unreal conditional in the latter quotation which shows her anger at the cruel way she is treated. According to what she says, old people are reduced to whimpers, cries, belches, and the rumblings of their stomach, which, she implies, is unfair (p. 107). Grandma is highly tormented by what she continually hears, and her interruption of the others' speech shows her ethical resistance to the violent arena she has to keep staying in. What attracts attention is the treatment she is subjected to on account of being nothing other than a useless old woman waiting for the end, which is death. Her comic hooting "Who? Who?" (p. 109) - deserves emphasis since it forces the audience to suppose or assume menacing proportions of the others whom the house waits for. Grandma's situation - her apparent reluctance in being carted off, by some vehicle people, to some unknown locations, directions, and destinations - is disturbing to the senses.

With the obstruction of the gateways for empathy, sympathy, and understanding, and with the euphemistic, baby-talk tone, The American Dream ferociously, uproariously, "fairly and squarely" attacks the distinct "ideals of progress, optimism, and faith in the national mission", criticizes the newly-formed values, and heaps scorn on sentimental ideals such as family life, togetherness, the 
pleasant feeling of being united, and physical fitness (Esslin, 2004, p. 312). Knowing that her end is near, Grandma has lovingly wrapped her boxes which contain such disparate things as "some old letters, a couple of regrets ... [a blind] Pekinese ... the television ... [her] Sunday teeth . . . eighty-six years of living . .. some sounds ... [and] a few images" (Albee, 2007, p. 143). The boxes, which house her life and her memories, are "the emptiness around which [one] wrap[s] [his or her] illusions" (Paolucci, 1972, p. 35). The time left to her becomes less and less, while the beautifully wrapped boxes, the witnesses to much better days, accumulate. The feeling of being on the threshold of the ultimate end, which is death, and the thought, retrospection, that death makes possible gives expression to the particular process whereby one's own life becomes an absolute object which is worthy of examination. During moments of violent social intercourse, the audience sees Grandma setting apart from the spectacle before her, due to her marginality.

Lack of identity in modern man results in many complications, many social and psychological problems, and ends up with the intensification of the motif of the meaninglessness of life. In the various definitions of hell, Sartre proposes, a pattern shows itself: Hell is intrinsically related to existence and one's particular idea of oneself; and therefore, the key element of hell in Sartre's play is the absence of certain "mirrors" or reflective surfaces (Sartre, n.d., p. 2). The characters have no other alternative apart from relying on each other to create their identities; thus, Estelle asks Inez to describe her beauty, while Inez begs Estelle to love her, and Garcin wants Inez to tell him that he is not a coward. Although they at first wanted to be alone, the characters definitely need each other; and, the play is essentially a map of their thwarted desires, of their inability to control their personal image. And, it is this lack of ability which paves the way for the climactic paradox. When finally free to leave, Garcin refuses to do so; and, according to what he says, he has to stay just because of Inez. Unable to live with each other and unable to live without each other, the characters are trapped not only physically, but also emotionally and morally. In The American Dream, one can feel the echoes of these: Since she married Daddy and let him "bump [his] uglies" (Albee, 2007, p. 106), Mommy - whose emotions are all rooted in undiluted selfishness - feels she has the right to his money when he dies. Regardless of the feelings of the others around her, she is capable of casual cruelty. Being direct in accomplishing the purpose she has in her mind, she insults in her self-righteousness. This again shows the violent nature of the 'American Scene' by highlighting what must remain unspoken in social intercourse: The meaning is that Mommy - who seems to be a gold digger kind of person - used to provide Daddy with sex, and this leads to the issue of the obscene. Their need for each other is further exemplified in Mommy's words, which she utters after Grandma's disappearance, while feeling anxious about her whereabouts, and 
while struggling not to cry: "There's no such thing as the van man. ... [W]e made him up. Grandma? Grandma?” (p. 144).

Related to the very specific point of the obscene, a crucial clarification has to be made: The etymology of 'obscene' is 'off scene', which means 'out of sight'. Grandma's conscious anti-social behaviour, generally involving ironic commentary on the events before, prefigures, foreshadows, her final leave, and thus, her transformation into the director: "[L]et's leave things as they are right now . . . while everybody's happy ... while everybody's got what he wants ... or everybody's got what he thinks he wants. Good night, dears." (Albee, 2007, p. 148). She sets herself apart from the intercourse to comment on it; and, her escape from the frame of action is, in a way, something unavoidable. Grandma leaves upon finding, upon devising a solution for the dilemma of the family. Most important of all, her ultimate exit removes her from the violent, and sometimes almost unendurable, power games in the house. And, by her intentional act of stepping out of the action, she not only reveals but also proves herself as the only character who is capable of staying away from the general collapse of individual identity and moral purpose. Interrupting the communicative function of speech is one of her defenses against the waves of violence. Furthermore, the "baking contest" (p. 136) which Grandma mentions at an earlier point in the play is worthy of highlighting, as it represents her plan by which she wants to "escape her dependence" on the others; and, it is the $\$ 25,000$ prize of the contest which eventually helps her in her endeavours to get out of the violent frame of action (Canaday, 1966, p. 32).

\section{THE ACT OF MUTILATION AND THE PERVERSION OF THE AMERICAN DREAM}

The consumerism of a mass society leads to a mindless pursuit of wealth which, by giving less importance to social values, and by undermining the need for socially acceptable behaviours, creates an atmosphere stripped of emotions. In The American Dream, Albee deals with American materialism, conformity, and the ideal of conventional family life as an essential part of that Dream. He depicts the dehumanizing effect by providing the audience with his upsetting condemnation of American values. He condemns a hollowness in American values which is not the result of inadequacy at all, but of some sort of deliberate choice. The world is portrayed as a problematic, arbitrary place where nothing seems to make much sense. Exchange value has taken the place of human value; "appearance is mistaken for substance"; and, authentic, genuine, values can only be "inferred from their absence" (Bigsby, 2000, p. 129). The parody of the conventional American life, which enhouses layers of meaning between the lines, shows the superficiality of much of life. 
The American Dream was not that kind of an ideology that could survive on its own. In the play, the current situation, the status quo, of the American family is shown by their withdrawal to pursue material things, forgetting all about their responsibilities in realizing the Dream. At one stage, Mommy and Daddy - both of whom represent the people of society - cannot find anything in the apartment. Daddy even loses "Grandma's room"; and, Mommy cannot find "the water" (Albee, 2007, p. 129), which itself shows the pureness of the old American Dream going away, fading away, and perhaps, ultimately becoming history.

Grandma, who is treated like a naughty child, tells the horrific story of the child to Mrs. Barker who delivered the "bumble of joy" (Albee, 2007, p. 126) to Mommy and Daddy two decades ago. The absurd failure of Mrs. Barker - who is the volunteer from the Bye-Bye Adoption Service which clearly puns on BuyBuy, and who stands for government, corporations, and "organizations" (Canaday, 1966, p. 30) - to understand Grandma's thinly veiled story is among the various defenses which are built against bringing the traumatic origin and purpose of her visit forward. The audience is presented with the information that Mommy, in the course of disciplining, has mutilated a child without pity, showing her malign side. The child was chopped off, and now that it has shown its unsatisfactory way by dying, Mommy and Daddy want compensation, a suitable replacement for the faulty product which they had purchased years ago, an eternal "satisfaction" although it is "the way things are today; you just can't get satisfaction" (Albee, 2007, p. 102). It takes the form of a dilemma, a source of conflict and violence, when there is a huge discrepancy between what one wants and what one gets. The controlling, but at the same time uncaring ways and attitudes of Mrs. Barker - a caricature of the socially responsible American housewife - stand for what the majority of American society is transforming into (p. 113).

Since the parents never feel fully satisfied with the things they have, they even go so far as to destroy something in their greedy quest to improve what they have. According to the story Grandma tells the audience, one night, the child "cried its heart out". Since the child "only had eyes for its Daddy" (Albee, 2007, p. 127), Mommy, in a moment of inhumanity, gouged its eyes out; since it called Mommy a dirty name, they cut its tongue out; and, since "it began to develop an interest in its you-know-what", they castrated it, and cut its hands off at the wrists. Perhaps, more painful than the physical mutilations and tortures are the verbal ailments: "[I]t didn't have a head on its shoulders, it had no guts, it was spineless, its feet were made of clay ... just dreadful things" (p. 128). Due to acting out on its desires, the child had to suffer a progressive disfigurement as its punishment; and, the punishments chosen for him were specifically directed at his bodily excesses and infantile desires. The fierce picture of the massacre of the adopted infant is nothing, but bloodcurdling. In addition to these conspicuous accounts of 
the violent actions which were performed in the past, verbal violence succeeds in taking the matter to new and multi-layered dimensions.

The dismemberment of the child calls to mind Sigmund Freud's well-known notion of the hypochondriac's 'organ speech', in which some irritating, vexing, ideas are translated into bodily effects. In accordance with the idea behind Freud's 'organ speech' - a kind of linguistic disturbance seen in schizophrenia which consists of expressing a particular relationship to a bodily organ or function Mommy not only violates the child's body physically, but also disfigures language, violently literalizing a certain figure of speech and collapsing it onto the human body. The schizophrenic speech, which has a hypochondriac quality, becomes organ language; and, the relation to the bodily organ takes the place of all "thought[s]" (Freud, 1963, p. 144). In the play, where there is a parallelism between the language used and the violence perpetrated on the child, the language and the body are simultaneously disfigured in only a single movement, in only a single gesture. The corporeal disfigurements all involve a disfigurement of language; there is disfigurement both corporeally and rhetorically.

When the figurative language of The American Dream involves a turn to the human body, the individual speech act gains a greater and greater importance, and language's performative potential for violence becomes much more apparent. For instance, related to the operation he had, Daddy talks about "misgivings" and "definite qualms" (Albee, 2007, p. 116), like a hypochondriac. Grandma laments that people think old people just complain because old people are "gnarled and sagged and twisted into the shape of a complaint" (p. 117): Due to the fact that the bodies mime what they say, it is right to assert that language, in a quite violent way, manifests itself on the body. The disfigurement of language results in the disfigurement of the child: Right after Mommy discovers that the child only has eyes for his father, she blinds him, only because of his affection for his father. Thus, turning directly to the body, she makes the figure of speech come true. Mommy is frightening because she disrupts not only the homosocial kind of bonds, son-father, but also the fraternal relation within the family in question. The violence she performs on the particular figure of speech involves a violent linguistic mechanism.

Needless to say, Mommy's mutilation, massacre, of the boy for his bodily excesses and infantile desires is violence at its most extreme form. The situation being so, the arrival of the Young Man, a negative entity of sorts, is far from surprising, as he can be interpreted as the direct result of Mommy's violent act of dismemberment. Grandma's assertions about old people becoming 'twisted' and their living "in the age of deformity" (Albee, 2007, p. 119) set the scene for conversations that are even more obsessed with shapes, and that revolve around the issue of appearances, and thus, can be considered as multi-dimensional pieces of language. The Young Man's twin brother bears every kind of deformation; as 
a result of the "difficult delivery", Mommy came into existence with a bananashaped head (p. 120); and, Daddy is disfigured through emasculation. In the play, where emasculation, impotence and incomplete sexual gestures are specifically used as a metaphor for unfulfilled aspirations, desires, and misdirected social powers and personal energies, the disfigurations and deformities symbolize what Albee calls the 'slipping land' that the nation has become. The corporeal disfigurements, within themselves, contain a disfigurement of language, and these issues again lead to the theme of language and violence. When Grandma says that what she intends to say might not accord with what she means, she, once more, shows language's endless capacity for violence: "I don't know if that's what I meant or not. It's certainly not what I thought I meant" (p. 116).

Whereas the child is mutilated physically, the American Dream is mutilated emotionally. When the iconic, "almost insultingly good-looking" Young Man, whom Grandma calls "the American Dream" (Albee, 2007, p. 133), appears on the stage, the audience concludes that the American Dream is not an ideology, or something which one lives out. Simultaneous with the appearance of the gorgeous Young Man, who is not only the personification of the American Dream, but also a prospective son, a hiatus, a pause, is introduced into the violent intercourse and the careening conversational games of the house. After the killing of his twin, the Young Man is nothing but - according to his self-description - "a type" (p. 137) in his physiognomy, outwardly perfect, but robbed of his inner life and real substance. He is made up of only muscles; he has a healthy exterior, but is dead inside, devoid of real feelings and capacity for any kind of lively experience.

Starting with his "identical", "not fraternal", twin with whom he lied "in the placenta" and shared an unfathomable kinship, the Young Man - whose double image is nothing other than the fragmented bits and pieces of a perverted identity - makes a long speech about the story of his countless losses, talks about his brother's blindness which ended his ability to see with pity (Albee, 2007, p. 138), and about a pain in his "groin" which left him unable to love anyone with his body. He arouses intense feelings of sympathy when he says that he "no longer [has] the capacity to feel anything". And, he goes on to say that he "[has] no emotions", and that he "[has] been drained, torn asunder ... [and] disemboweled" (p. 139). He might be referred to as the paragon of all the superficial characteristics Americans favoured; however, inside his handsome - seemingly anaesthetized - shell, there is nothing, but a void: Being deprived of all excitements, his infirmity is indescribable. With his emotional life being smothered and extinguished, he is left as a cripple, whose warmth has been taken away. He is a person who has been tortured by continuous mutilation of his soul and his spirit, and the deadening of his 'feeling' flesh. He is aware of his own predicament; and, he is, in a way, an abstraction. His incomprehensible mutilations coincide with those suffered by the baby who was adopted and 
destroyed mercilessly by Mommy. His twin, by whose mutilation the Young Man has been sympathetically affected, had to suffer a progressive sort of disfigurement under the inhumane dictates and discipline of Mommy, whose obnoxiously unpleasant manners offends and infuriates the audience. As opposed to all the battle-like talk going on, Grandma's words - to the Young Man, who instinctively recognizes her as a beautiful soul and kindred spirit - "Oh, my child; my child" (p. 139) attracts considerable attention: Her line is the only noticeable sign of familial affection within the boundaries, within the violent atmosphere of The American Dream.

In the 20th century American way of life, which is characterized by an emptiness of spirit that absolutely requires emptiness to surround it, individuals go through the ritualistic motions of loving and caring for one another; however, in reality, there is no genuine feeling, as normal feelings and relationships have become deprived of meaning. In a place where an externally perfect, superficially attractive and flawless Young Man turns into a child who gives 'satisfaction', it may be quite right to consider Mommy and Daddy's focus on the boxes' wrapping as a sign of their satisfaction with surfaces. Grandma, whose boxes signify the contents of the old American Dream, realizes that the Young Man is an excellent replacement for the adopted child, so she introduces him to the family, intending to restore the long-lost sense of domestic bliss. Ironically, the Young Man eventually becomes the long-desired child that Mommy believes will provide her with much satisfaction. The Young Man, the symbol of incommunicability and the impossibility of human contact, represents the new age American Dream. The old version of the Dream is imagined as a mask disemboweled of man and his excesses; and, there is the frustration which springs from the disparity, dissimilarity, between things as they are and things as they ought to be. In this sense, the Young Man is no one other than "the existential question made flesh" (Paolucci, 1972, p. 34).

Becoming the venal foster son, and willing to do "anything that pays", "anything for money", anything provided that "there's money in it", the Young Man is, in a way, their commodity, the merchandise, the 'replaceable' product, which they have greedily dreamt of all along. The Young Man's insatiable appetite for money - "Do you have any money?" (Albee, 2007, p. 135), "I do what I'm paid to do. I don't ask any questions" (p. 140) - and the play's constant emphasis on the word 'satisfaction' in fact show the substitution of material things for the most important values in life. With echoes of capitalism, an extension of cruelty, in the background, it is possible to sense the unattainable satisfaction and the violence inherent in the 20th century American family. What remains in the house is "a family of marionettes ... as absurd as the American Dream itself". Albee is far from recommending the beautiful or sexually attractive "Adonis as an ideal." $\mathrm{He}$ does not intend to glorify narcissism, vanity or egocentrism; however, he intends 
to show them "as the fruits of an upbringing" by a certain type of woman (Debusscher, 1967, p. 41).

\section{CONCLUSION}

In the light of all the crucial points which have been taken into consideration so far, it is possible to assert that a culture with waning values and weakening norms can no longer provide peaceful living environments for individuals. The misconceptions which surround the valuable Dream and the emergence of new ideals in the mid-century America - at the expense of the conventional, traditional, values - prepare the undesirable conditions for domestic unrest, and by extension, violence. It becomes apparent that the apathetic characters, who are presented as symbols more than as individuals, are rather opposing states of the human mind/conscience of guilt and indifference; and, they unite to create a Sartrean existential hell for each other. The superimposition of meaning on appearance and the lack of sincere conversation contribute to an air of mistrust, and thus trust erosion, which is embodied in the peevish and dishonest attitudes, power struggles, querulous tones, and brawls. In a society that relies on euphemisms, societal expressions which purposefully cover and conceal reality, artificiality reigns; and, in case of artificiality, individuals turn to words of aggression, and thus, resort to violent expressions of speech. The irrelevant nature of the language reflects the meaninglessness of life and shows that language as gesture has taken the place of language as communication. The fatuousness of the dialogues and the arid language used not only reflect, but also amplify a conviction that some social conventions and some public myths have corrupted the individual self; and, as a result, a threat is directed against individual freedom. It is such an era of conformity that it is as if American values are processed, insistently mass produced, and less individualized; and, people, who are powerless to act as individuals, choose to follow the crowds, and are dragged towards a violent language, a language in which harmony of rhythm and content cannot be achieved. Instead of being fixated on their roles - as mother, father, etc. - in the family structure, the family members are fixated on their roles as consumers; and, this is one of the reasons which gives rise to the violent language used in the living environment. The reversal of the matriarchal and patriarchal roles, the act of mutilation which rocks the middle-class morality and ethics to its very foundations, and the dual action of the corporeal and rhetorical disfigurement can only transform a house into a violent arena, where it is difficult to even breathe. Due to continuously clashing over societal expectations, most of the characters cannot succeed in getting back on their feet; and, to make things even worse, while waiting for a beacon of hope, it is hope itself which fades into the background. 


\section{REFERENCES}

Albee, E. (2006). Stretching My Mind. New York: Carroll \& Graf Publishers, An Imprint of Avalon Publishing Group Inc.

Albee, E. (2007). The American Dream. In The Collected Plays of Edward Albee (Vol. 1, pp. 95-148). New York and London: Overlook Duckworth.

Berkowitz, G. M. (1992). American Drama of the Twentieth Century. New York: Longman Publishing.

Bigsby, C. W. E. (2000). Edward Albee: Journey to Apocalypse. In Modern American Drama: 1945-2000 (pp. 124-153). Cambridge: Cambridge University Press.

Canaday, N. (Winter, 1966). Albee's 'The American Dream' and the Existential Vacuum. The South Central Bulletin, Studies by Members of SCMLA, 26 (4): 28-34. The Johns Hopkins University Press on behalf of The South Central Modern Language Association. Retrieved January 10, 2021, from https://www.jstor.org/stable/3187819

Cohn, R. (1969). Edward Albee. Minneapolis: University of Minnesota Press.

Debusscher, G. (1967). Edward Albee: Tradition and Renewal. (A. D. Williams, Trans.) Brussels: American Studies Center.

Esslin, M. (1988). The Field of Drama: How the Signs of Drama Create Meaning on Stage and Screen. London: Methuen Publishing Limited.

Esslin, M. (2004). The Theatre of the Absurd (3rd ed.). New York: Vintage Books.

Freud, S. (1963). The Unconscious. In P. Rieff (Ed.), General Psychological Theory (C. M. Baines, Trans., pp. 116-150). New York: Collier Books, Macmillan Publishing Company.

Innes, C. (2005). Avant Garde Theatre: 1892-1992. London and New York: Routledge.

Oberg, A. K. (Summer, 1966). Edward Albee: His Language and Imagination. Prairie Schooner, 40 (2): 139-146. University of Nebraska Press. Retrieved January 10, 2021, from https://www.jstor.org/stable/40629152 
Paolucci, A. (1972). The Existential Burden: 'The Death of Bessie Smith', 'The Sandbox', 'The American Dream', 'The Zoo Story'. In From Tension to Tonic: The Plays of Edward Albee (pp. 15-44). Carbondale and Edwardsville: Southern Illinois University Press.

Sartre, J. P. (n.d.). No Exit. Retrieved January 5, 2020, from https://archive.org/details/NoExit

Shiach, D. (2007). American Drama: 1900-1990. Cambridge: Cambridge University Press.

Styan, J. L. (1996). Modern Drama in Theory and Practice (Vols. 2: Symbolism, Surrealism and the Absurd). Cambridge, New York, Melbourne: Cambridge University Press.

Szondi, P. (1987). Theory of the Modern Drama: A Critical Edition (Vols. Theory and History of Literature, 29). (M. Hays, Ed., \& M. Hays, Trans.) Minneapolis: University of Minnesota Press.

Unwin, S., \& Woddis, C. (2001). A Pocket Guide to 20th Century Drama. New York: Faber and Faber Inc. 